\title{
Flaccid penile length and stretch factor in the newborn.
}

\author{
Adekoya, A.O. ${ }^{1,2}$, Fetuga, M.B. ${ }^{2}$, Ogunlesi, T.A. ${ }^{2}$, Adekoya, A.O. ${ }^{3}$, Oba-Daini, O.O. ${ }^{2}$, \\ Ajibola, E.D.
}

\begin{abstract}
Objective: Little is known about the flaccid penile length in the newborn and the degree of stretch of the penis among investigators while measuring the stretched penile length. This study aimed to document the flaccid penile length and the stretch factor in the newborn.
\end{abstract}

Methods: This cross-sectional study was carried out on 200 term male infants within the first 72 hours of life. The flaccid penile length and the stretched penile length were measured with a wooden spatula and the stretch factor was calculated.

Results: The mean $( \pm \mathrm{SD})$ flaccid and stretched penile length were $30.9 \pm 3.8 \mathrm{~mm}$ and $38.9 \pm 4.0 \mathrm{~mm}$ respectively. The mean stretch factor was $26.4 \%$. Both testes had the same mean volume of $1.6 \pm 0.5 \mathrm{ml}$. There was a significant correlation between flaccid and stretched penile lengths $(r=0.775, p=0.000)$. The flaccid penile length was a significant predictor of the stretched penile length.

Conclusion: This study has been able to determine the stretch factor while measuring the flaccid and stretch penile lengths in Nigerian newborn infants. It is recommended that the flaccid penile length be measured along with the stretched penile length and determine the stretch factor in order to compare how much investigators stretch the penis during measurement. This will allow for detailed comparison of penile anthropometry across different ethnic groups and races.

Keywords: flaccid penile length, newborn, stretch factor, stretched penile length.

Corresponding author

Adekoya, O.A.

ORCID-NO: http://orcid.org/0000-0002-0515-7002

E-mail: adekoyaa@babcock.edu.ng

${ }^{1}$ Department of Paediatrics, Babcock University Teaching Hospital and Ben Carson School of Medicine, Babcock University, Ilishan-Remo, Ogun State, Nigeria.

${ }^{2}$ Department of Paediatrics, Olabisi Onabanjo University Teaching Hospital, Sagamu, Nigeria

${ }^{3}$ Department of Radiology, Olabisi Onabanjo University Teaching Hospital, Sagamu, Nigeria.

Research Journal of Health Sciences subscribed to terms and conditions of Open Access publication. Articles are distributed under the terms of Creative Commons Licence (CC BY-NC-ND 4.0). (http://creativecommons.org/licences/by-nc-nd/4.0).

http://dx.doi.org/10.4314/rejhs.v9i1.3 


\title{
Longueur du pénis flasque et facteur d'étirement chez le nouveau-né
}

\author{
Adekoya, A.O. ${ }^{1,2}$, Fetuga, M.B. ${ }^{2}$, Ogunlesi, T.A. ${ }^{2}$, Adekoya, A.O. ${ }^{3}$, Oba-Daini, O.O. ${ }^{2}$, \\ Ajibola, E.D. ${ }^{1}$
}

\section{Résumé}

Contexte général de l'étude: On sait peu de choses sur la longueur du pénis flasque chez le nouveau-né et le degré d'étirement du pénis parmi les enquêteurs lors de la mesure de la longueur du pénis étiré. Cette étude visait à documenter la longueur du pénis flasque et le facteur d'étirement chez le nouveau-né.

Méthode de l'étude : Cette étude transversale a été réalisée sur 200 nourrissons nés à terme de sexe masculin au cours des 72 premières heures de vie. La longueur du pénis flasque et la longueur du pénis étiré ont été mesurées avec une spatule en bois et le facteur d'étirement a été calculé.

Résultat de l'étude : La longueur moyenne $( \pm \mathrm{ET})$ du pénis flasque et étiré était de 30,9 $\pm 3,8 \mathrm{~mm}$ et 38,9 \pm $4,0 \mathrm{~mm}$ respectivement. Le facteur d'étirement moyen était de $26,4 \%$. Les deux testicules avaient le même volume moyen de 1,6 $\pm 0,5 \mathrm{ml}$. Il y avait une corrélation significative entre les longueurs de pénis flasques et étirées $(\mathrm{r}=0,775, \mathrm{p}=0,000)$. La longueur du pénis flasque était un prédicateur significatif de la longueur du pénis étiré.

Conclusion: Cette étude a été en mesure de déterminer le facteur d'étirement tout en mesurant les longueurs de pénis flasques et étirés chez les nouveau-nés nigérians. Il est recommandé de mesurer la longueur du pénis flasque avec la longueur du pénis étiré et de déterminer le facteur d'étirement afin de comparer la mesure dans laquelle les investigateurs étirent le pénis pendant la mesure. Cela permettra une comparaison détaillée de l'anthropométrie pénienne à travers différents groupes ethniques et races.

Mots-clés: longueur du pénis flasque, nouveau - né, facteur d'étirement, longueur du pénis étiré

\author{
*Corresponding author \\ Adekoya, O.A. \\ ORCID-NO: http://orcid.org/0000-0002-0515-7002 \\ E-mail: adekoyaa@babcock.edu.ng
}

\footnotetext{
${ }^{1}$ Department of Paediatrics, Babcock University Teaching Hospital and Ben Carson School of Medicine, Babcock University, Ilishan-Remo, Ogun State, Nigeria.

${ }^{2}$ Department of Paediatrics, Olabisi Onabanjo University Teaching Hospital, Sagamu, Nigeria.

${ }^{3}$ Department of Radiology, Olabisi Onabanjo University Teaching Hospital, Sagamu, Nigeria.
} 


\section{INTRODUCTION}

Historically, the stretched penile length (SPL) was first described by Schonfeld and Beebe (1) and this has become the conventional method of measuring penile length in the newborn. The SPL correlates closely with the length of erect penis compared with the flaccid length (2). Other methods such as ultrasonography (3) and the syringe method (4) have also been used to measure the SPL.

For clinicians and researchers, a major importance of the SPL is to determine normal penile length and consequently identify babies with abnormal sizes viz micropenis and macropenis; as these are associated with different potentially endangering conditions such as congenital adrenal hyperplasia and congenital hypopituitarism $(5,6)$ It is therefore pertinent that there should be no under- or over-stretching while measuring the penile length, so as to avoid creating skewed references and thus, the wrong diagnoses (7). Globally, reference values generated from different communities on SPL have shown ethnic and racial variations in penile sizes in the newborn (7-13).

The flaccid penile length (FPL) in the newborn scarcely exists in published literature. Similarly, the stretch factor (SF), which is a measure of how much the investigator stretches the penis, is described for the first time in live newborns in this work. The SF, which is a function of percentage increase, is calculated as the SPL minus FPL, divided by the FPL and expressed in percentage (14). It cannot be assumed that the SF is comparable across all investigators, as there have been no previously generated data in live newborns to support this. It is also important to know how much individual investigators stretch the penis while measuring, as this may have significant influence on comparisons of data across different populations.

Feldman and Smith who worked on formalin-fixed spontaneous and induced abortus, compared SPL and FPL measurements and reported an appreciable 18\% difference between the mean values, denoting the degree of stretch (2). This finding raises a pertinent question: if the degree of stretch varies among investigators, will comparisons of normative data on stretched penile length in the newborn from different studies be unbiased? Stretch is subjective. It depends on how much force is exacted and how much elastic tissue is present. It is therefore important to measure the FPL alongside the SPL in order to know if there are variations in how much the penis is stretched across researchers.
The aim of this study was to document the FPL in the newborn, compare to SPL as well as determine the stretch factor.

\section{MATERIALS AND METHODS Study location and design}

This was a cross sectional, multi-centre study conducted in Sagamu, South-west Nigeria between April 2014 and March 2015. By convenience sampling, two hundred term male infants of consecutive births were selected from a cohort of newborns who were recruited from a teaching hospital, two specialist private hospitals and two primary health centres, to establish normative data for stretched penile length for the locale (7). A sample size of 200 has been documented to be adequate for the estimation of reference range as it provides a stable reference range between the 2.5 and 97.5 percentiles with a $99 \%$ confidence level $(15,16)$.

\section{Recruitment and measurement of participants}

Babies delivered via uncomplicated spontaneous vaginal delivery between 37 and 41 completed gestational weeks and less than 72 hours of chronological age were recruited. The exclusion criteria included the presence of dysmorphic features, ambiguous genitalia, cryptorchidism, hypospadias, epispadias and penile curvature. The authors applied questionnaires to obtain relevant parental, obstetric and neonatal history. Maternal last normal menstrual period, an early pregnancy ultrasound report in addition to the New Ballard Score (17) were applied to determine the gestational age.

With the baby in the supine position and the hips abducted, the FPL was measured, without traction, along the dorsum from the pubo-penile junction with a wooden spatula pressed against the pubic ramus to eliminate the pre-pubic fat as much as possible. The tip of the glans penis was palpated, excluding the prepuce and a mark corresponding to this point was made on the spatula. The measurement was read with a digital caliper (VWR International, Model 62379-531) to the nearest millimeter. The SPL was measured was also measured on the dorsum of the penis. A wooden spatula was gently pressed against the pubic ramus and the penis was stretched to a point of increased resistance. The assistant marked the spatula at a point corresponding to the tip of the glans penis, excluding the prepuce. The measurement was also read with a digital caliper (7). 
The testicular volume was measured using a standard Prader orchidometer (Model B01GDNHC4). The scrotal skin was stretched taut over the testis and the ellipsoid volumes of the orchidometer were compared by visual inspection with the testes and the nearest to the testis size was chosen. Each testis was measured separately and a testicular size between two ellipsoid volumes was taken as the mean volume for each testis. When the testes were unequal in size, a mean value was calculated (10). The principal investigator (AOA) carried out all the penile and scrotal measurements. Every measurement was taken twice and the average adopted. The body weight, length, head and chest circumference were measured as previously described (7). The body temperature of all the participants was normal at the time of measurement.

The stretch factor was calculated using the formula (14) SPL-FPL x 100

\section{FPL}

\section{Statistical analysis}

The data were analysed using the Statistical Package for the Social Sciences (SPSS) for Windows version 20.0 (IBM SPSS Statistics, IBM Corporation, Armonk, NY, USA). Means and standard deviations [documented as mean $\pm \mathrm{SD}$ ] were compared using analysis of variance (ANOVA). The 3rd, 25th, 50th, 75th and 97th percentiles of large datasets of continuous variables were derived accordingly. A histogram was used as graphical illustration. Pearson correlation coefficient ( $r$ ) was used to assess the relationship, and linear regression was also used to determine the strength of the relationship between two sets of continuous data. Statistical significance was defined by $p$ values less than 0.05 .

\section{Ethical considerations}

The study had approval from the Ethical Review Committee of Olabisi Onabanjo University Teaching Hospital, Sagamu, Nigeria and was documentarily permitted by the Medical Officer of Health, Sagamu Local Government Area. Mothers or guardians of recruited babies gave a written informed consent prior to the commencement of measurements and were present throughout the measurements.

\section{RESULTS}

The mean $( \pm \mathrm{SD})$ weight, length, head circumference and chest circumference were 3.1 $\pm 0.4 \mathrm{~kg}, 49.2 \pm 2.0 \mathrm{~cm}, 35.2 \pm 1.3 \mathrm{~cm}$ and $32.5 \pm$
$1.9 \mathrm{~cm}$ respectively. The FPL ranged from $20.5-$ $40.1 \mathrm{~mm}$, with a mode of $29.4 \mathrm{~mm}$. The mean $( \pm$ SD) FPL and SPL were $30.9 \pm 3.8 \mathrm{~mm}$ and 38.9 $\pm 4.1 \mathrm{~mm}$ respectively. The mean SF was $26.4 \%$. Both right and left testes had the same mean volume of $1.6 \pm 0.5 \mathrm{ml}$. The testes were unequal in 22 babies (11\%) with the left bigger in 12 of them. Table 1 depicts the gestational-aged based mean values for SPL and SF. As the gestational age increased, the FPL increased. Conversely, the SF reduced with increasing gestational age. However, there was no statistically significant difference between the mean values. The mean testicular volume was similar across the gestational ages.

The $3^{\text {rd }}, 50^{\text {th }}$ and $97^{\text {th }}$ percentiles for the FPL were $23.4 \mathrm{~mm}, 31.0 \mathrm{~mm}$ and $38.6 \mathrm{~mm}$ respectively. Gestational age-based percentiles for FPL were also derived (Table 2). The pattern observed across each percentile was non-specific as the values increased for the $25^{\text {th }}$ percentile with increasing gestational age. However, the observation was dissimilar in other percentiles. In assessing the reliability between the first and second measurements of FPL taken by a single investigator, the intra-class correlation coefficient was $0.960-0.977$ at $95 \%$ confidence interval while the Cronbach's alpha value was 0.97 .

There was a significant and strongly positive correlation between FPL and SPL $(\mathrm{r}=$ $0.775, p=0.000)$. The FPL had a significant but weak correlation with the GA $(\mathrm{r}=0.167, \mathrm{p}=$ 0.018 ) but not with any of the anthropometric parameters; weight $(r=0.093, p=0.188)$, length $(r=0.068, p=0.338)$, head circumference $(r=$ $0.032, \mathrm{p}=0.651)$ and chest circumference $(\mathrm{r}=$ $0.029, \mathrm{p}=0.684)$. There was no correlation between the testicular volume and the gestational age as well as the anthropometric parameters. There was also no correlation between FPL and $\mathrm{TV}(\mathrm{r}=-0.007, \mathrm{p}=0.926)$. Linear regression was run to predict SPL from FPL. The flaccid penile length significantly predicted SPL as denoted by the regression equation $\mathrm{SPL}=13.3+0.83(\mathrm{FPL})$. The coefficient of determination $\left(\mathrm{R}^{2}\right)$ was 0.600 and $\mathrm{p}<0.005$.

\section{DISCUSSION}

The penis, being an erectile organ, is responsive to varying degrees of stretch up to its maximum limit. The extent of stretch is influenced by the amount of force applied and the expertise of the investigators, and may thus be subjective. It is presently known that SPL is shorter in Asian compared to Caucasian and 
African newborns $(7,11,12)$. However, it is not known if FPL varies among ethnicities. Interestingly, the mean FPL observed in this study is similar to the SPL in some Asian countries such as China and South Korea $(11,13)$, and also comparable to penile corporeal (corpus) length determined by ultrasonography in the flaccid state (18). This further supports the finding that SPL is higher in Nigerian infants compared to non-Nigerians (7).

The composition of collagen, smooth muscle fibres and elastic system fibres, which all contribute to penile stretch and erectility, have been studied in cadaveric human fetuses. The collagen content of the corpus spongiosum was found to be higher than the corpus cavernosum. Also, collagen content in the spongiosum was significantly higher than the mounts of smooth muscle and elastic fibre systems (19). It is not yet known if there is a differential expression among ethnic or racial groups as there is no study presently that has compared penile collagen composition and distribution among different populations. If the SF is similar, it may suggest that the composition of these fibres is similar.

The SF can only be determined by measuring the FPL along with the SPL. The SF in this study is higher than reported by Feldman and Smith in formalin-fixed cadaveric samples (2). This is not surprising because of the nature of the samples. Although not statistically significant, the observations that the FPL increased with increasing gestational age and the SF reduced with increasing gestational age are noteworthy. The findings may suggest that there are more elastic fibres in babies delivered at lower gestational age. More studies are needed to confirm or dispute the observations.

In this study, a strongly positive correlation was found between FPL and SPL and it was established by linear regression that FPL is a good predictor of SPL. There is paucity of data on FPL in the newborn to compare with. The findings of this study do not in any way undermine previous reports on SPL but rather suggest that more be done in comparing penile length sizes in the newborn. Although the clinical relevance of FPL in the newborn has not been previously discussed, its significant predictability of the SPL as observed in this study makes it worthy of consideration for diagnostic purposes. In adults, penile length estimation is not limited to SPL. Reference ranges for FPL have also been documented to diagnose abnormally small and large penile sizes $(20,21)$, and are being used to determine individuals who may benefit from penile augmentation (21).

The testicular volume in this study is comparable to that reported in Enugu (22) but bigger than observed in Ibadan, Nigeria (23), using the same instrument to measure. Contrary to the observation of Chikani et al (22), the testicular volume did not increase with increasing gestational ages, suggesting that the testicular volume is similar in term newborn infants. Previous studies have documented a significant but weak positive correlation between the testicular volume and the birth weight $(22,23)$, but this study found no correlation. The difference in the sample sizes may have an effect on this but, it should be noted that testicular growth and volume in the foetus and newborn is mainly by the effects of gonadotropins on the normal testes (24). The strength of this study is that all the genital measurements were taken by a trained paediatric endocrinologist and it describes, for the first time, the stretch factor in live newborns.

\section{CONCLUSION}

This study has generated a percentile table for FPL and also determined the SF in the newborn. These parameters are presently rare in existing literature. The SF provides information on how much each investigator stretches the penis. This will enable more detailed comparison of penile sizes in the newborn and help determine the stretchability of the penis in each population. We therefore recommend that SPL should be measured alongside FPL.

Acknowledgement: We hereby acknowledge the contributions of Drs. Akinola Balogun and Ayobami Owonifari to the success of this project.

Financial support and sponsorship: The project received a part-funding from the European Society for Paediatric Endocrinology (ESPE). and the Global Paediatric Endocrinology and Diabetes (GPED, www.globalpedendo.org).

Conflict of interest: None declared.

\section{REFERENCES}

1. Schonfeld WA, Beebe GW. Normal growth and variation in the male genitalia from birth to maturity. J Urol. 1942;48:759-7.

2. Feldman KW, Smith DW. Fetal phallic growth and penile standards for newborn males. J Pediatr. 1975;86:395-8

3. Khairil OA, Zulfiqar A, Thambidorai CR, Nizam JM, Ahmad JT, Jamil MA. Ultrasound 
measurement of corporeal (penile) length in newborns. Med J Malaysia. 2005;60:469-74.

4. Özbey H, TemizA, Salman T. A simple method for measuring penile length in newborns and infants. Brit J Urol Int. 1999;84:1093-4.

5. Alqahtani MA, Shati AA, Zou M, Alsuheel AM, Alhayani AA, Al-Qahtani SM, et al. A Novel Mutation in the CYP11B1 Gene Causes Steroid $11 \beta$-Hydroxylase Deficient Congenital Adrenal Hyperplasia with Reversible Cardiomyopathy. Int J Endocrinol 2015;2015:595164.

6. Salisbury DM, Leonard JV, Dezateux CA, Savage MO. Micropenis: an important early sign of congenital hypopituitarism. Br Med J (Clin Res Ed). 1984;288:621-2.

7. Adekoya AO, Fetuga MB, Jarrett OO, Ogunlesi TA, Chanoine JP, Oba-Daini OO. Normative data on penile and ano-genital measurements of term male infants in Sagamu, Nigeria. Acta Paediatr. 2019;108:2041-7.

8. Elusiyan JB, Ojetayo FG, Fajola AO. Penile dimensions of newborns at Obio cottage hospital, Port Harcourt. Nigeria. Niger Postgrad Med J 2016;23:67-70.

9. Asafo-Agyei SB, Ameyaw E, Chanoine J-P. Nguah SB. Normative penile anthropometry in Kumasi, Ghana: a crosssectional prospective study. Int. J Pediatr Endocrinol 2017;2017: 2.

10. Ting TH, Wu LL. Penile length of term newborn infants in multiracial Malaysia. Singapore Med J. 2009;50:817-21.

11. Fok TF, Hon KL, So HK, Wong E, Ng PC, Chang A, et al. Normative data of penile lengths for term Chinese newborn. Biol Neonate. 2005;87:242-5.

12. Kutlu AO. Normative data for penile length in Turkish newborns. J Clin Res Ped Endo. 2010;2:107-10

13. Kim SY, Jun JS, Lee SG. Normative data of penile length in Korean newborns. Korean J Pediatr. 2008;51:944-9.

14. University of Leicester. Student learning development - Working with percentages. A v a i l a b 1 e

$f \mathrm{r} o \mathrm{~m}$ https://www2.le.ac.uk/offices/ld/all- resources/numerical-data/percentages. Last accessed on $15^{\text {th }}$ June, 2020

15. Lott JA, Mitchell LC, Moeschberger ML, Sutherland DE. Estimation of reference ranges: how many subjects are needed? Clin Chem. 1992;38:648-50.

16. Hussein NS, Abid AF, Alnuaimi AS. Reference range of flaccid and stretched penile lengths of adult males in Baghdad: A cross-sectional study. Arab J Urol. 2017;15(1):68-73.

17. Ballard JL, Khoury JC, Wedig K, Wang L, EilersWalsman BL, Lipp R. New Ballard Score, expanded to include extremely premature infants. J Pediatr. 1991;119:417-43.

18. Khairil OA, Zulfiqar A, Thambidorai CR, Nizam JM, Ahmad JT, Jamil MA. Ultrasound measurement of corporeal (penile) length in newborns. Med J Malaysia. 2005;60(4):469-74.

19. Gallo CB, Costa WS, Furriel A, Bastos AL, Sampaio FJ, Kellermayer MS. Modifications of erectile tissue components in the penis during the fetal period. PLoS ONE. 2014;9(8):e106409.

20. Chen XB, Li RX, Yang HN, Dai JC. A comprehensive, prospective study of penile dimensions in Chinese men of multiple ethnicities. Int J Impot Res. 2014;26(5):172-6.

21. Wessells H, Lue TF, McAninch JW. Penile length in the flaccid and erect states: guidelines for penile augmentation. J Urol. 1996;156(3):995-7.

22. Chikani UN, Ibekwe MU, Chinawa JM, Adimora GN. Testicular volume of healthy term neonates: Determination of normative values among Igbo babies in South-Eastern Nigeria. Niger J Clin Pract 2016;19:85-90.

23. Ogundoyin OO, Olulana DI, Lawal TA, Ajao A. Measurement of testicular volume in healthy Nigerian newborns at Ibadan, Nigeria using the Prader orchidometer. J West Afr Coll Surg 2016;6(3):39-48.

24. Lambert A-S, Bougneres P. Growth and descent of the testes in infants with hypogonadotropic hypogonadism receiving subcutaneous gonadotropin infusion. Int $\mathrm{J}$ Pediatr Endocrinol 2016;2016:13

How to cite this article:

Adekoya, A.O., Fetuga, M.B., Ogunlesi, T.A., Adekoya, A.O., Oba-Daini, O.O., Ajibola, E.D. Flaccid penile length and stretch factor in the newborn. Research Journal of Health Science, 2021, 9(1): 23-29 
Table 1: Gestational age-based flaccid penile length, stretch factor and testicular volume.

\begin{tabular}{lllll}
\hline GA (weeks) & N (\%) & $\begin{array}{l}\text { FPL (Mean } \\
\pm \text { SD, mm) }\end{array}$ & SF (Mean, \%) & $\begin{array}{l}\text { TV average (Mean } \\
\pm \text { SD, mls) }\end{array}$ \\
\hline $\mathbf{3 7}$ & $19(9.5 \%)$ & $29.5 \pm 4.8$ & 30.2 & $1.6 \pm 0.5$ \\
$\mathbf{3 8}$ & $39(19.5 \%)$ & $30.1 \pm 3.5$ & 26.5 & $1.7 \pm 0.4$ \\
$\mathbf{3 9}$ & $57(28.5 \%)$ & $31.3 \pm 4.0$ & 26.3 & $1.6 \pm 0.5$ \\
$\mathbf{4 0}$ & $49(24.5 \%)$ & $31.2 \pm 3.5$ & 26.1 & $1.6 \pm 0.5$ \\
$\mathbf{4 1}$ & $36(18.0 \%)$ & $31.7 \pm 3.1$ & 25.9 & $1.6 \pm 0.5$ \\
\hline & & $\mathrm{F}=1.749$ & $\mathrm{~F}=0.642$ & $\mathrm{~F}=0.229$ \\
& & $\mathrm{p}=0.141$ & $\mathrm{p}=0.633$ & $\mathrm{p}=0.922$ \\
\hline
\end{tabular}

GA - Gestational age, F - ANOVA, FPL - flaccid penile length,

$\mathrm{SD}$ - Standard deviation, SF - Stretch factor.

Table 2: Gestational age-based percentiles for flaccid penile length.

\begin{tabular}{lccccc}
\hline $\begin{array}{l}\text { GA } \\
\text { (weeks) }\end{array}$ & $\mathbf{3}^{\text {rd }}$ & $\mathbf{2 5}^{\text {th }}$ & $\mathbf{5 0}^{\text {th }}$ & $\mathbf{7 5}^{\text {th }}$ & $\mathbf{9 7}^{\text {th }}$ \\
\hline $\mathbf{3 7}$ & 20.5 & 25.8 & 29.4 & 33.6 & 36.5 \\
& & & & & \\
$\mathbf{3 8}$ & 23.9 & 27.5 & 29.3 & 32.4 & 39.1 \\
$\mathbf{3 9}$ & 23.2 & 28.2 & 32.0 & 34.1 & 39.3 \\
$\mathbf{4 0}$ & 23.3 & 29.2 & 31.2 & 33.4 & 39.9 \\
$\mathbf{4 1}$ & 26.0 & 29.6 & 31.5 & 33.8 & 39.0 \\
GA - Gestational age, $\mathrm{N}-$ number.
\end{tabular}

